\title{
Pavement energy harvesting technologies: a critical review
}

\author{
Domenico Vizzari $^{1 *}$, Eric Gennesseaux ${ }^{1}$, Stéphane Lavaud ${ }^{1}$, Stéphane Bouron ${ }^{1}$, Emmanuel Chailleux $^{1}$
}

${ }^{1}$ Université Gustave Eiffel, Allée des Ponts et Chaussées, 44340 Bouguenais - Nantes, France

Received: 18 November 2020 / Accepted: 12 July 2021 / Published online: 20 August 2021

(C) The Author(s) 2021. This article is published with open access and licensed under a Creative Commons Attribution 4.0 International License.

\begin{abstract}
The world energy consumption is constantly increasing and the research point towards novel energy harvesting technologies. In the field of pavement engineering, the exploitable sources are the solar radiation and the vehicle load. At present, these systems are able to convert the sunlight into electricity thanks to some solar cells placed under a semi-transparent layer (photovoltaic roads), or they can harvest thermal heat by means of solar thermal systems. The thermal gradient of the pavement can be exploited by thermoelectric generators, by heat pipes or by heat-transfer fluids (i.e. water) pumped into a medium (asphalt solar collectors, porous layer or air conduits). The traffic load can be exploited by piezoelectric materials, able to convert the vehicle load into an electrical charge.

The aim of this paper is to describe the main pavement energy harvesting technologies, pointing out positives and negatives and providing indications for further optimizations. Finally, the systems are compared in terms of initial cost, electrical output, efficiency and technology readiness level.
\end{abstract}

Keywords: Energy harvesting; Road pavement; Comparison; Electrical output; Efficiency; Technology readiness level; Greenhouse gas emission

\section{Introduction}

Energy harvesting is the process by which energy is captured exploiting an external source (e.g., solar power, thermal energy, wind energy, electromagnetic ambient energy, kinetic energy, etc.) [1, 2]. In the field of road engineering, the exploitable energy sources are the solar radiation and the vehicle load (Figure 1).

The first group is related to technologies that make use of the solar exposure of the road pavement. The sunlight can be converted into electricity thanks to solar cells imbedded into a semi-transparent layer, or it can be converted in thermal heat by means of solar thermal systems. The thermal gradient of the pavement can be exploited by thermoelectric generators (TEGs), by heat pipes or by a heat-transfer fluid pumped into a medium (asphalt solar collectors, porous layer or air conduits) [3].

The second group is composed by technologies that make use of the mechanical energy transferred from vehicles to the pavement. The load can be converted into electricity by means of piezoelectric material imbedded into the asphalt, or by speed bumps, able to transform the motion and pressure generated by passing of a vehicle into energy [4].

\section{Photovoltaic road}

A photovoltaic road aims at converting the sunlight in electricity thanks to the solar cells placed under a semi- transparent layer. The general design of a photovoltaic road consists of three principal layers (Figure 2): the top element is a semi-transparent layer made of tempered glass, polymer or glass aggregates bounded together using a special resin [5] (i.e. epoxy, polyurethane etc.).

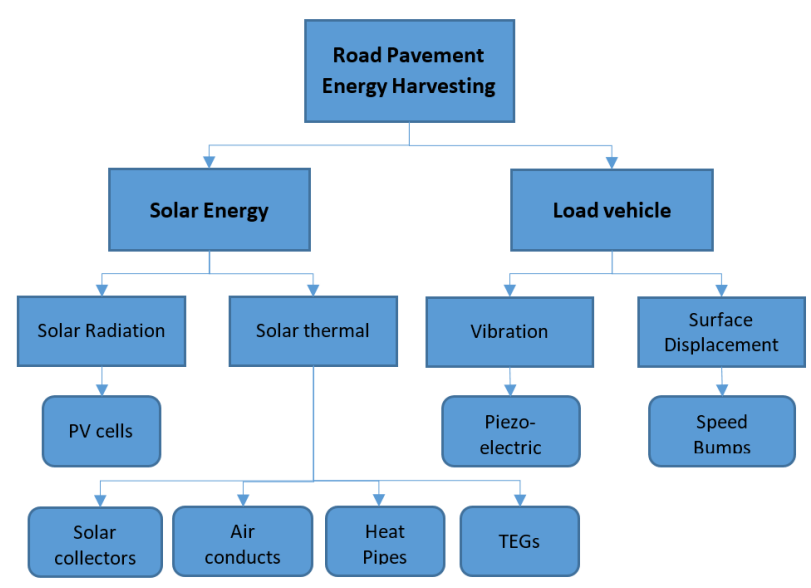

Figure 1. Energy harvesting through the road pavement.

The semi-transparent layer plays a fundamental role because it has to support the traffic load, ensure safe driving thanks to adequate adherence condition, allow the passage of the sunlight to the solar cells and protect the electronic component; the second element is the electric layer where

\footnotetext{
* Corresponding author: Domenico Vizzari, E-mail: domenico.vizzari@univ-eiffel.fr
} 
the solar cells are located and the last element is the base layer which has to transmit the traffic load to the pavement, subgrade or base structure [6].

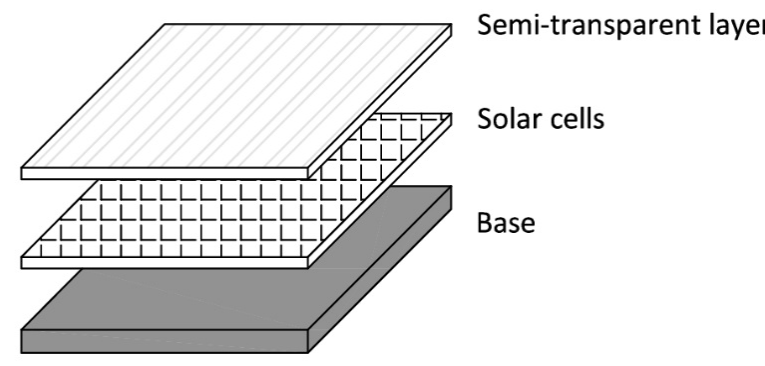

Figure 2. Exploded view of a photovoltaic road.

In academia, Northmore and Tighe [7] proposed a sandwich structure composed by two laminated $10 \mathrm{~mm}$ tick panes of tempered glass for the transparent layer, $12.7 \mathrm{~mm}$ and $19.1 \mathrm{~mm}$ thick panes of Glass fiber Polyester GPO-3 (a fiberglass laminate consisting of polyester resin reinforced with fiberglass mat base for applications up to $155^{\circ} \mathrm{C}$ with good thermal, mechanical and electrical properties [8]) for the electrical and the base layer respectively. In terms of mechanical performance, the photovoltaic road was able to support a stress of $16.6 \mathrm{MPa}$, which was the endurance limit (also called "fatigue limit", it is the stress level below which failure doesn't occur) of the fiberglass foil.

Dezfooli et al. [9] proposed two different prototypes in order to evaluate the feasibility of the photovoltaic roads. The first prototype is composed of a top layer in polycarbonate for the transmission of sunlight, a second layer contains the solar cells and finally an aluminum plate used to keep the layers together. The second prototype is composed of four parts: an asphalt layer to withstand the traffic load, the solar cells enclosed between two rubber layers and the top porous layer to drain and channel the water and to protect the solar cells. Based on the results of the flexural bending test, the first prototype was able to support $600 \mathrm{kPa}$ before the failure.

$\mathrm{Ma}$ et al. [10] designed a photovoltaic floor, where the solar cells, enclosed by two EVA (Ethylene Vinyl Acetate) /PVB (Polyvinyl Butyral) foils, are sandwiched between anti-slip front tempered glass and rear support tempered glass. The total front size is $500 \times 500 \mathrm{~mm}$ and the thickness is about 20 $\mathrm{mm}$. In each floor tile, 9 mono-crystalline silicon solar cells are connected in series, generating an electrical power of 30-40 $W_{p}$ (it is the Watt-peak and it represents the maximum power supplied by a solar cell in standard conditions) and ensuring an efficiency of $15 \%$. The maximum compressive strength for the photovoltaic floor was around 15-16 MPa.

Comparing the three solutions, the tempered glasses of Northmore et al. and Ma et al. seem to be adapted to support the traffic load, which is around $1 \mathrm{MPa}$ for a heavy truck. The disadvantage of these systems is that they are all prefabricated structures, whose application in full scale could be complex and expensive.

Photovoltaic roads also attracted industry attention. The Table 1 lists the principal companies, which built full scale prototypes.
Comparing the photovoltaic roads developed by industry, the solution of Wattway seems to be the easiest to install, because the panel can be directly placed on existing pavements. Regarding the electrical output, a correct comparison is not feasible because the data provided by the companies are not obtained following a standard procedure (i.e. irradiance of $1000 \mathrm{Wh} / \mathrm{m}^{2}$ and temperature of $25^{\circ} \mathrm{C}$ ). Furthermore, phenomena such as the reduction of the efficiency of the pv cells at high temperatures, aging of the top layer and presence of dirt or dust are not taking into account for the calculation of the electrical power.

\subsection{COP21 prototype}

Researchers of IFSTTAR showed growing interest for photovoltaic road and, in occasion of the COP21 (Conference of Paris - 2015), they presented a novel prototype of "hybrid solar road". The system was composed by a semi-transparent layer of $1 \mathrm{~cm}$ thick, a porous asphalt layer of $10 \mathrm{~cm}$ thick able to harvest heat energy by means of water and a pv cell placed between the two layers [15].

The semi-transparent layer was obtained by mixing together recycled glass aggregates with an epoxy transparent binder. In general, the semi-transparent layer was treated as an asphalt mixture. The binder content was around $5 \%$ and it was optimized in order to obtain a certain fluidity of the mixture and to give a satisfying visual aspect of entire grain surface coating without any visible binder leakage.

Once the mix-design was defined, the optical performance of the semi-transparent layer has been tested. In particular, the power loss of the solar cell because of the semi-transparent layer has been measured. The results showed that the power loss of the mixture having $1 \mathrm{~cm}$ thick was around $52.9 \%$. Furthermore, the reduction of optical performance was detected by exposing the sample to the weather changes. The power loss moved from $52.9 \%$ to $71.7 \%$.

In terms of mechanical performance, a static load has been applied on a sample composed by the semi-transparent layer stuck on a concrete slab of $7 \mathrm{~cm}$ thick. The charging area had a diameter of $44 \mathrm{~mm}$. The charging force was transmitted to the sample surface via a hard rubber interface extracted from utilized tires. The sample withstood to $9500 \mathrm{~N}$, which is equivalent to $6.25 \mathrm{MPa}$ of compression stress. Considering that the maximum stress of a heavy truck on a road pavement is around $1 \mathrm{MPa}$, the result was satisfactory.

Unfortunately, the epoxy is affected by aging, which causes brittleness and yellowing. Recent research proposes to replace the epoxy with thermosetting polyurethane, which is more stable to the UV radiations. Furthermore, the mixdesign of the semi-transparent layer is optimized. The results demonstrate that high glue content (up $20 \%$ in volume) has a positive impact on both mechanical and optical performance of the semi-transparent layer, while the use of fine particles, which interfere with the sunlight wavelength, reduces dramatically the transparency of the material $[16,17]$. 


\begin{tabular}{|c|c|c|c|}
\hline Company & Description & $\begin{array}{l}\text { Electrical } \\
\text { output }\end{array}$ & Applications \\
\hline $\begin{array}{l}\text { Solar } \\
\text { Roadways } \\
{[11]}\end{array}$ & $\begin{array}{l}\text { They proposed a hexagonal panel of around } 0.4 \mathrm{~m}^{2} \\
\text { composed by an electrical layer (containing the solar } \\
\text { cells) enclosed between two layers of tempered glass } \\
\text { hermetically sealed. Furthermore some LED lights are } \\
\text { imbedded into the pavement to make road lines and } \\
\text { signage }\end{array}$ & $\begin{array}{l}44 \text { Wh per } \\
\text { panel }\end{array}$ & \\
\hline $\begin{array}{l}\text { Wattway } \\
{[12]}\end{array}$ & $\begin{array}{l}\text { Colas company designed panels containing } 15-\mathrm{cm} \text { wide } \\
\text { polycrystalline silicon cells that transform solar energy } \\
\text { into electricity. The cells are coated in a multilayer } \\
\text { substrate composed by resins and polymers, } \\
\text { translucent enough to allow the passage of the } \\
\text { sunlight, and resistant enough to withstand truck } \\
\text { traffic }\end{array}$ & $\begin{array}{l}20 \mathrm{~m}^{2}+1000 \\
\text { sun-hour/year } \\
\text { to provide } \\
\text { energy for an } \\
\text { average single } \\
\text { French } \\
\text { household }\end{array}$ & $\begin{array}{l}\text { - A parking lot of } 50 \mathrm{~m}^{2} \text { in Vendéspace } \\
\text { (Roche-sur-Yon) able to produce } 6300 \\
\mathrm{kWh} / \text { year } \\
\text { - } 50 \mathrm{~m}^{2} \text { of panels have been installed at the } \\
\text { Georgia Visitor Information Center, } \\
\text { producing } 7000 \mathrm{kWh} / \text { year } \\
\text { - } 1 \mathrm{~km} \text { of Wattway road have been installed } \\
\text { in Normandy, producing } 280 \mathrm{MWh} / \text { year }\end{array}$ \\
\hline $\begin{array}{l}\text { Solaroad } \\
{[13]}\end{array}$ & $\begin{array}{l}\text { The technology consists of concrete modules of } 2.5 \\
3.5 \text { meters with a translucent top layer of tempered } \\
\text { glass, which is about } 1 \mathrm{~cm} \text { thick. The top layer has to be } \\
\text { translucent for sunlight and repel dirt as much as } \\
\text { possible. At the same time, it must be skid resistant and } \\
\text { strong enough in order to guarantee a safety drive }\end{array}$ & $\begin{array}{l}3500 \\
\text { kWh/year per } \\
\text { module }\end{array}$ & $\begin{array}{l}\text { - A bike path of } 72 \text { meters built in } \\
\text { Krommenie (Netherland) which produces } \\
70 \mathrm{kWh} / \mathrm{m} 2 \text { per year }\end{array}$ \\
\hline $\begin{array}{l}\text { Qilu } \\
\text { transportation } \\
{[14]}\end{array}$ & $\begin{array}{l}\text { The structure is typical of a solar road: semi- } \\
\text { transparent layer }+ \text { pv cells + base layer }\end{array}$ & $460 \mathrm{Wh} / \mathrm{m}^{2}$ & $\begin{array}{l}\text { - A road of } 1 \mathrm{~km}(5875 \mathrm{~m} 2) \text { built in Jinan } \\
\text { (China), able to produce } 1 \mathrm{GWh} / \text { year }\end{array}$ \\
\hline
\end{tabular}

\subsection{Sensecity prototype}

In 2016, a big scale experimental mounting of a solar road was installed in the site of the SenseCity experimental platform located in Marne-la-Vallée near Paris. The installation was representative of real urban conditions involving partial shading from adjacent building, trees and masts and can be circulated by pedestrian, bicycles and light vehicles. The system was constructed on a $195 \times 85 \mathrm{~cm}^{2}$ concrete slab and it consisted of three parallel connected PV panels of $60 \mathrm{~W}$ each covered by $1 \mathrm{~cm}$ of semi-transparent layer designed in IFSTTAR (Figure 3) [18].

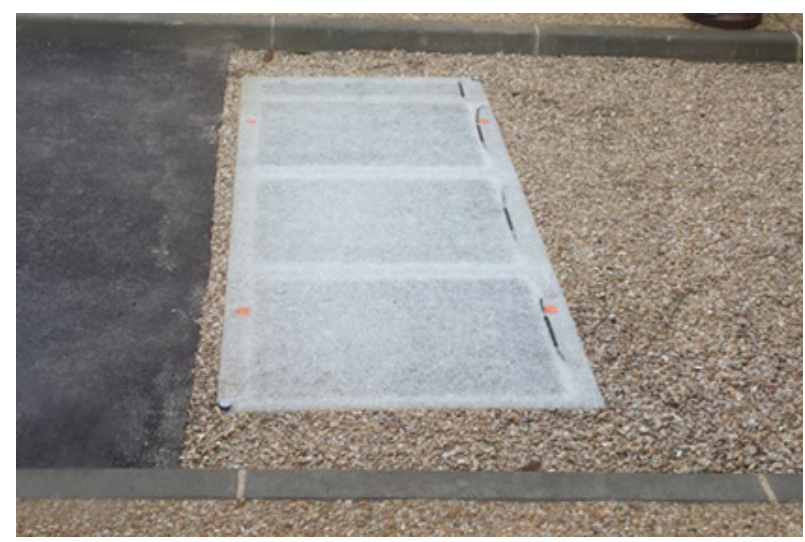

Figure 3. Sensecity prototype [18].

The electrical power (see Annexes 1 and 2) of the prototype and the global irradiance was measured for 2 months from $6: 30 \mathrm{am}$ to $6: 30 \mathrm{pm}$. The Figure 4 is an example of measurements obtained on the $1^{\text {st }}$ of May 2016. The upper part represents the produced PV electric power in blue, the global irradiance measured by the pyranometer (It is a device able to measure the global irradiance (direct + diffuse sunlight, see Annex 3) Solems RG-100 reference cell in green and the global irradiance measured by an SPN1 pyranometer installed on a 10-meter mast near the solar road, in magenta.

The lower part of Figure 4 refers to the efficiency of the prototype, given by the ratio between the electric power and the irradiance received by the RG100. The measurements refer to an area of $1 \mathrm{~m}^{2}$ and they are around $8 \%$ between 10:00 am and 2:00 pm.

Observing the trend of the efficiency curve, there is a decrease between 10 am and $1 \mathrm{pm}$, which is certainly due to the heating of the solar cells.

Before 8:15 am, both the prototype and the pyranometer Solems RG-100 were shaded by the building and the tree on the east. After that, the sun started shining on the sensor again (as seen through the large jump in the green curve), and progressively, the 3 modules of the solar road became partially to fully exposed to the sunshine. This progression is seen through the 3 main steps in the blue curve between 8:30 and 10:30 am. Between 11:30 and 12:00 am, the 10 meters mast overshadowed the solar road. Symmetrical effects occurred at sunset. 


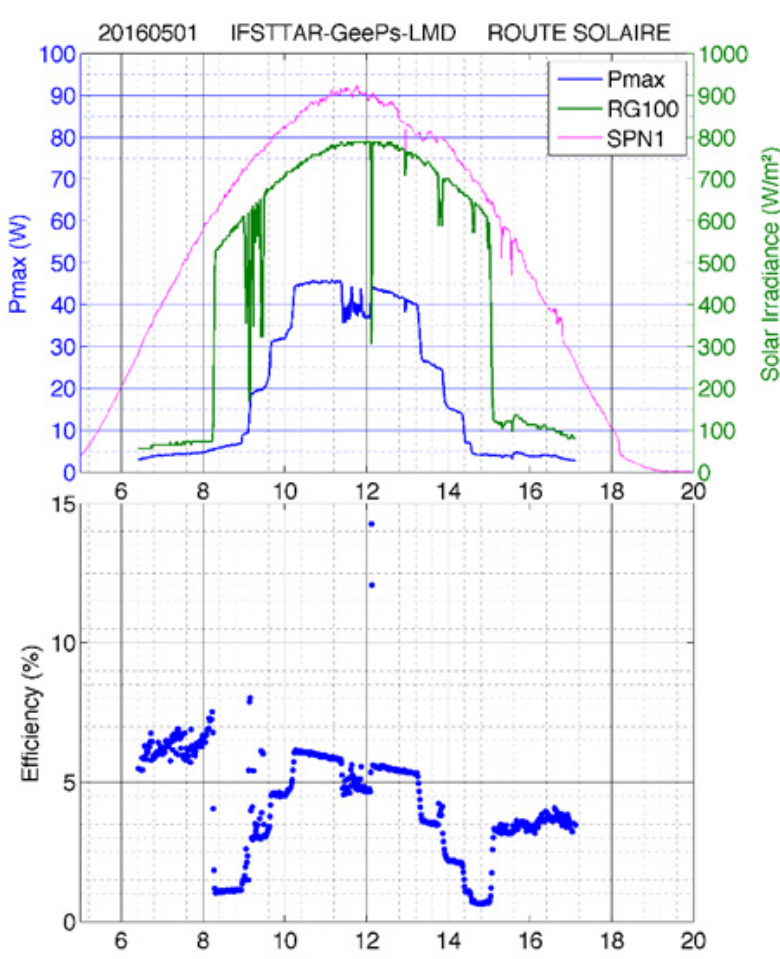

Figure 4. Measurements on the solar road - 1st of May [18].

The maximum power obtained during the measurements was $160 \mathrm{Wh}$ and it was reached between 10:00 am and 2:00 pm during a sunny day.

Figure 5 shows the ratio between electric produced energy and the irradiation detected by the pyranometer, around noon (10:00 am - 2:00 pm). It is a pseudo conversion efficiency because the irradiance received by the solar road is affected by many shadowed period while the pyranometer is not affected. Anyhow, the figure clearly shows a degradation of the solar cells performance. This declining tendency is due to the aging of the epoxy and dirt accumulation.

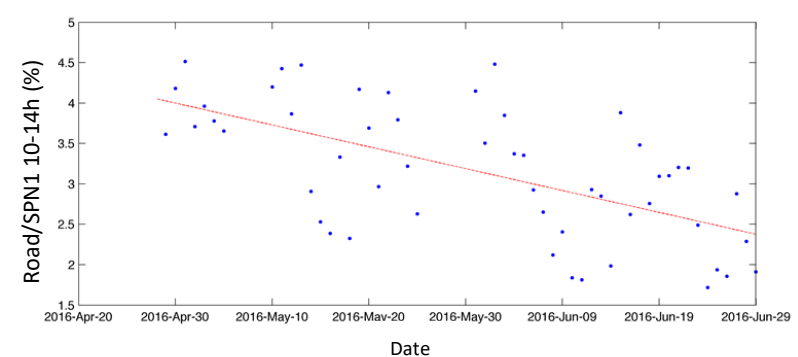

Figure 5. Daily energy produced by the solar road divided by the daily irradiance measured by the pyranometer from April 6th to June $30^{\text {th }}$ 2016 [18].

\section{Solar thermal systems}

Solar thermal systems are able to harvest heat energy from the Sun by means of a heat-transfer fluid. Based on the medium used to make flow the heat-transfer fluid, two systems can be distinguished: asphalt solar collectors and porous layer as active solar collectors. If the heat-transfer fluid is the air, the system is called air-powered energy harvesting pavement.

\subsection{Asphalt solar collectors}

Because of the sunlight exposition, the surface temperature of asphalt can increase around $70^{\circ} \mathrm{C}$, accelerating some typical failure of the roads as the rutting (permanent deformation of pavements) or the oxidation of the asphalt (causing changes in viscosity, separation of components, embrittlement and loss of cohesion) [19]. In order to reduce the pavement temperature and exploit the solar radiation, asphalt solar collectors represent a good solution. They consist of pipes, directly embedded into the asphalt, able to extract heat energy through a fluid (i.e. water). Due to the temperature gradient between the fluid and the asphalt, a heat transfer process occurs from the pavement to the fluid. In other terms, a cold fluid goes into the system and a hot fluid comes out.

The energy obtained from the asphalt solar collectors could be used for snow melting systems or for the heating system of the adjacent buildings. The solar collectors can also be embedded in concrete pavements, but they are less performant because the concrete's solar absorption coefficient is lower than asphalt.

The energy balance of an asphalt solar collector involves the following materials and media: i) the asphalt pavement, ii) the pipes, iii) the air of the atmosphere and iv) the fluid flowing through the pipes network. In terms of heat exchange mechanisms, the energy is firstly balanced along the interface between pavement and atmosphere. In this case, the heat flux is caused by the incident solar radiation, by the convection between asphalt and air and by the thermal radiation of the asphalt. In return, the heat flux causes a change of temperature in the pavement, leading to a conduction process from the surface to the interior of the road. The conduction continues in the interface asphalt-pipe and finally a convection mechanism occurs in the interface pipe-fluid.

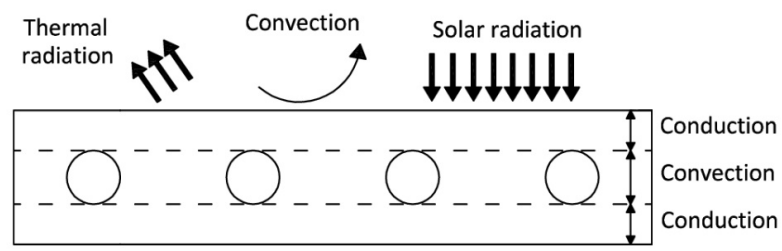

Figure 6. Energy balance of an asphalt solar collector.

The first application of asphalt solar collectors dates back to 1990 with SERSO project [20]. The pipes network was installed along a bridge in Swiss, which was part of the national highway. The idea was to store the excess of heat energy during summer thanks to a heat pump and reuse the heat in order to melt the snow or the ice during the winter.

Compared to other road energy harvesting systems, the asphalt solar collectors have reached the highest level of improvement, becoming a quite common technology with a lot of applications in operational environment. For example, ICAX company designed a pipes network that use water as 
heat-transfer fluid [21]. The heat energy is stored in a heat store constructed beneath the insulated foundation of the buildings around. OOMS [22], a Dutch company, designed a system for the extraction of cold water from a specific underground storage medium (in the Netherlands often an aquifer). The water is transported through pipes in the upper part of the asphalt layers of the pavement and, thanks to the heat exchange, the water gets warm. Via a heat exchanger, the heat is transported into another underground reservoir (the so-called hot store) and held at this location until required. In winter, the system operates in the opposite way.

\subsection{Porous layer as solar thermal system}

A multi-layer asphalt pavement for energy harvesting is a sandwich structure able to exploit the harvested energy for de-freezing the road surface during winter. The first prototype proposed by IFSTTAR and CEREMA was a defreezing system inspired by the asphalt solar collectors. In this system, the tubes were replaced by a draining asphalt through which a heat-transfer fluid circulated via gravity. The prototype has been evaluated in terms of durability, stain behavior, water permeability and thermal effectiveness. Furthermore, two types of porous layers have been tested: $a$ conventional porous asphalt and an asphalt with polyurethane binder having $22.5 \%$ and $30 \%$ of porosity, respectively. The results showed a better mechanical performance for the second asphalt [23].

\subsection{A 2-D hydrothermal model}

In 2016, Asfour et al. [24] developed a 2D thermo-hydraulic model to simulate the thermal heat exchanges of a fluid circulating in a bonding porous layer. The pavement was composed of a porous asphalt enclosed between a wearing and a base layer. The authors assumed a stationary hydraulic regime, transient thermic solicitations and that the hydraulic parameters are independent of temperature. Once the model was defined, a sensitivity analysis of the temperature at the pavement surface has been conducted. The results highlighted that the surface temperature is mostly affected by the hydraulic conductivity of the porous asphalt layer, the fluid injection temperature and the fluid calorific capacity.

The hydraulic conductivity has been measured experimentally by means of a laboratory mock-up. The mockup was composed of a wearing course layer of asphalt concrete having $0.06 \mathrm{~m}$ thick; a bonding course layer of 0/14 porous asphalt $0.08 \mathrm{~m}$ thick and a base layer of asphalt concrete $0.05 \mathrm{~m}$ thick. The hydraulic conductivity was 2.2 $\mathrm{cm} / \mathrm{s}$, for a porosity of $20 \%$ and a slant of $1 \%$.

At the same time, Pascual-Muñoz et al. [25] from the Cantabria University worked on a multilayered solar collector at lab scale. The prototype had dimensions $40 * 26 * 9 \mathrm{~cm}^{3}$ and it was composed by three layers: i) a gap-graded asphalt mixture having $2 \mathrm{~cm}$ thick; ii) a porous asphalt mixture having $4 \mathrm{~cm}$ thick and iii) a dense-graded asphalt mixture having $4 \mathrm{~cm}$ thick.

The authors tested two types of porous asphalt concrete with 23 and $27 \%$ of porosity and two different configurations: saturated and not-saturated porous layer.
The first configuration has been rejected because the water filtered across the top layer. For this reason all the tests have been conducted in not-saturated condition.

Unlike the prototype of Asfour et al, the water was not put back in circulation by a pump, but it was a continuous flow coming from a tap. The hydraulic gradient between the inlet and the outlet of the system was maintained constant thanks to an inlet tank, which was able to release the overflow by a hole located at a certain height.

The solar radiation was simulated by a lamp of $300 \mathrm{~W}$, which generated an irradiance of 300,370 or $440 \mathrm{~W} / \mathrm{m}^{2}$. The results showed that the hydraulic conductivity across the porous layer can be significantly improved by increasing the porosity.

The authors measured the collected energy and they observed that the lower is the hydraulic conductivity (and consequently the porosity), the more difficult it is for the fluid to collect energy. In terms of efficiency, defined as the ratio between the energy transferred to the fluid and the energy absorbed by the surface, it was higher than 0.75 when the porosity is $27 \%$, instead it dropped to 0.4 when the porosity was $23 \%$. In perspective, they concluded that the harvested energy could be increased by maximizing the porosity of the middle layer or by increasing the slope of the system.

\subsection{FEM model of porous layer as solar thermal system}

In 2017, Le Touz et al. [26, 27] developed a multi-physics FEM model of multi-layer asphalt pavement for energy harvesting. The system is composed by a semi-transparent (or an asphalt mixture called "opaque") waterproof layer; a porous layer containing a fluid which flows along the width of the road via gravity thanks to the imposed slope; an underlying and a base layer both opaque and waterproof. The model combines thermal diffusion, hydraulic convection and radiative transfer.

The structure is subjected to convective exchange with the air, radiative exchange with the sky and solar radiation. The depth is supposed to be large enough in order to neglect all the thermal exchanges except at the surface.

Regarding the hydraulic convection, the hypothesis are that the flow of the fluid is stationary, low and uniform and that the porous layer is in saturated condition; while, for the radiative transfer, blackbody emissions at ambient temperature for main wavelengths of solar radiation can be neglected.

The authors coupled the three models in order to compute the temperature field in the structure and derive the harvested energy.

The harvested energy is given by the formula:

$$
E=\int_{t} \rho_{f} C_{p, f} u S\left(T_{f, \text { out }}-T_{f, \text { in }}\right)^{+} d t
$$

Where:

$\rho_{\mathrm{f}}$ is the density of the fluid $\left(\mathrm{kg} / \mathrm{m}^{3}\right)$;

$\mathrm{C}_{\mathrm{p}}$ is the heat capacity $\left(\mathrm{J} / \mathrm{kg}^{*} \mathrm{~K}\right)$;

$\mathrm{u}=1^{*} 10^{-4}$ is the Darcy velocity $(\mathrm{m} / \mathrm{s})$;

$\mathrm{S}$ is the section of the flow $\left(\mathrm{m}^{2}\right)$; 
$\left(T_{f, \text { out }}-T_{f, i n}\right)^{+}$is the temperature fluid raise between input and output (K);

$\mathrm{t}$ is the time (s).

Considering a length of the flow of $4 \mathrm{~m}$, the harvested energy per $\mathrm{m}^{2}$ was calculated for different location in France from May to October.

The efficiency of the system is given by the ratio between the harvested energy (Eq. 3) and the total solar irradiation. In the case of the opaque surface (asphalt mixture), the efficiency ranges between $31.1 \%$ and $41 \%$ based on the location. Using the semi-transparent surface, the solar radiation can penetrate deeply in the structure and the efficiency increases of about $7 \%$ by reference to the incident radiation.

\subsection{Air-Powered Energy-Harvesting Pavement}

The heat fluid in the asphalt solar collectors is essential to extract energy from the pavements. However, the presence of a crack in the pipes could compromise all the system, releasing the fluid and risking the failure of the pavement. The idea proposed by Chiarelli and Garcia $[28,29]$ is to imbed into the pavement a series of conduits, using the air as heat fluid. The air conduits are connected to an updraft and a downdraft chimney and, because of the difference of temperature between the environment and the asphalt, a difference of pressure exists between the end of the chimney and the entrance into the pavement.

The result is a continuous airflow, which can cool the pavement down during the summer or heat it up during the winter up to $10 \%$ of the initial temperature.

First results on a lab scale prototype demonstrated the feasibility of the system and highlighted that:

the lowest surface temperature along with the highest air speed is obtained installing the pipes in a single row under the pavement wearing course;

the pipes can be replaced with concrete corrugations, but they reduce the harvested energy;

the dimension of the chimney affects the final performance of the system. For this reason an optimal design is needed; the air flow of the prototype is around $0.58 \mathrm{~m} / \mathrm{s}$, not enough for electricity production.

\section{Heat pipes}

A heat pipe is a system able to transfer thermal energy quickly. It is sealed at both ends and it is lined with a wicking material [6]. At certain pressure and temperature, the system reaches the equilibrium between liquid and vapor state of the fluid enclosed in the pipe.

In particular, the internal liquid (into the wicking material) absorbs thermal energy from the pipe surface and it evaporates. Pressure forces move the vapor from the hot to the cold part of the pipe, where it releases the heat, condensing back into liquid. Finally, the capillary action from the wicking structure transports the liquid back and the cycle starts again [30].

The heat pipes have been applied as snow-melting system, using $\mathrm{CO}_{2}$ as heat-transfer fluid. Evaporated warm $\mathrm{CO}_{2}$ rises to the top of the heat pipe exploiting a geothermal heat sources. Once the $\mathrm{CO}_{2}$ reaches the surface, it condenses releasing the heat. After that, the $\mathrm{CO}_{2}$ returns to the vaporization zone of the heat pipe in liquid state, triggering an automatic cycle. The result is a heat pipe system able to melt the snow on the pavement without using any external energy [31].

In 1984, Nydahl proposed a heat pipe system using ammonia for de-icing a bridge in Wyoming. The diameter of the tubes was of $16 \mathrm{~mm}$ and the used material was the black iron [32].

Recently a system was built in Bad Waldsee (Germany) to cover the entrance of a fire station along a surface of $165 \mathrm{~m}^{2}$. The pipes have a diameter of $16 \mathrm{~mm}$ and they are connected to the surface through a shaft distribution system. Groups of 5 pipes converge in 5 boreholes at the depth of 50-75 $\mathrm{m}$ in order to study the differences of performances based on different pipes lengths [31]. In general, shorter is the distance of the pipes from the shaft the more efficient is heat system.

In 2017, Liu et al. [33] proposed a multi-objective optimization and a thermal simulation of a snow-melting system. The authors studied the influence of pipes embedded spacing, embedded depth and wind velocity on the total heating time for the melting process (THT) and on the lost energy rate absorbed by the environment (LER). Based on the results, the THT can be decreased by reducing the embedded spacing, the embedded depth and the wind velocity. On the contrary, the LER can be decreased by increasing the embedded depth and reducing the embedded spacing and the wind velocity. The optimum (lowest THT and LE) is given by an embedded spacing of $0.1 \mathrm{~m}$, an embedded depth of $0.06 \mathrm{~m}$ and absence of wind.

\section{Thermoelectric generators (TEGs)}

Thermoelectric generators (TEGs) produce electricity thanks to the Seebeck effect [34]. They are composed by thermoelectric couples consisting of n-type (containing free electrons) and p-type (containing free holes). In semiconductors, charge carriers have the ability to move freely while carrying charge as well as heat. In the presence of a temperature gradient, the charge carriers diffuse from the hot side to the cold side. The result is a net charge (negative for electrons and positive for holes) at the cold side, which produces an electrostatic potential (voltage). The voltage depends on the difference of temperature between the cold and the hot side, according to the Eq. 2:

$$
V=\alpha \Delta T
$$

Where: $\alpha(\mu \mathrm{V} / \mathrm{K})$ is the Seebeck coefficient and $\Delta \mathrm{T}(\mathrm{K})$ is the difference of temperature. For standard thermocouples, $\alpha$ ranges between 8 and $60 \mu \mathrm{V} / \mathrm{K}$ [35].

TEGs have been applied in road engineering as pavementcooling system. For example, Hasebe et al. [36] proposed to install a thermoelectric generator coupled with an asphalt solar collector. The heat-transfer fluid is the water coming from a source (i.e. a river or a lake) near the road. The water, circulating along the pipe network, is able to absorb heat from the pavement. Because of the heat, the temperature of the water increases and it is pumped in the hot side of the TEG. In return, the other side of the TEG is cooled down by the river 
water. Thanks to the temperature gap between the hot and the cold side, electrical power is generated. More in detail, for a $\Delta \mathrm{T}$ of $15^{\circ} \mathrm{C}$, the generated electrical power is around $0.3 \mathrm{~W}$.

In 2012, Wu and $\mathrm{Yu}$ [38] built a prototype able to harvest energy thanks to the temperature difference between the pavement surface and the subgrade soil. The prototype was composed by an aluminium plate and a rod installed in a hole, drilled along an asphalt sample. A TEG module was installed on the aluminium plate, using a conductive epoxy as interface. The other end of the rod was placed on dry sand, in order to simulate the subgrade soil.

The experiment was to simulate the solar energy through a filament lamp and measure the electrical power. Once the lamp was open, the TEG was able to generate a voltage of $300 \mathrm{mV}$.

The potential of TEGs was assessed by Guo et al. [37]. The authors calculated an electrical power of 55GWh per day, which could be generated if the entire road network of Florida was equipped with TEGs.

\section{Piezoelectric pavement}

In piezoelectric crystals, when a mechanical strain is applied to the material by an external stress tension, or compression, an electric charge occurs on the surfaces (Figure 7).

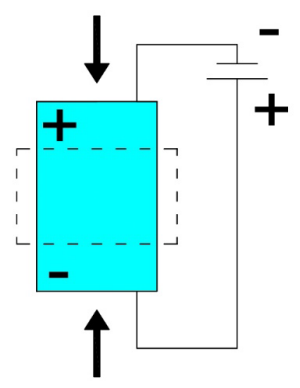

Figure 7. Piezoelectric effect.

Typical piezoelectric natural materials are quartz and amazonite, while barium titanite, lead titanite and lead zirconate titanite are artificial crystals.

Piezo-electric crystals can be imbedded into the pavement, for example along the interface between surface and binder course. When the vehicle (or the pedestrian) moves over the road, the wheel generates a pressure on the crystals. In return, the crystal undergoes a deformation, generating the electric charge $[39,40]$.

The energy produced by an external stress is given by the Eq. 3 [41]:

$$
U_{E}=\frac{1}{2} V_{0}^{2} \frac{\varepsilon_{r}^{t} \varepsilon_{0} A}{t}
$$

Where:

$U_{E}(J)$ is the electric energy storage in the piezoelectric device;

$V_{0}(V)$ is the electric potential in open circuit;

$A\left(m^{2}\right)$ is the area of the piezoelectric crystal;

$t(m)$ is the thickness of the piezoelectric crystal; $\varepsilon_{\mathrm{r}}(\mathrm{dim})$ is the relative dielectric constant piezoelectric crystal (is a parameter that indicates how easily a material can become polarized because of an electric field);

$\varepsilon_{0}(\mathrm{~F} / \mathrm{m})$ is the dielectric constant in vacuum piezoelectric crystal;

In 2013, Sun et al. [42] designed, based on a FEM analysis, a piezoelectric unit having dimensions $280 * 280 * 20 \mathrm{~mm}^{3}$. Each unit is composed by 64 piezoelectric vibrators and it can generate $0.25 \mathrm{~W}$ of electrical power at $15 \mathrm{~Hz}$ of load frequency, for a load of $0.7 \mathrm{MPa}$. The simulation showed that the system can harvest $1.785 \mathrm{MW}$ on each lane and per kilometer.

In 2016, Xiong et al. [43] presented a novel piezoelectric energy harvester (PEH). The system consists of piezoceramic disks sealed in a protective package. Six prototypes were fabricated and installed in a real road in order to evaluate the feasibility of the system. The average electrical power of each $\mathrm{PEH}$ is $3.106 \mathrm{~mW}$, considering that only $14.43 \%$ of the vehicles load was transmitted to the piezoelectric materials.

At the same time, Moure et al. [44] developed some piezoelectric cymbals having $29 \mathrm{~mm}$ diameter. The best configuration was given by 3 cymbals connected in series in a row transverse to the wheel movement. The system was integrated directly in the asphalt and, based on the results, each unit was able to generate an electrical power up to 16 $\mu \mathrm{W}$ when a truck wheel passed on the cymbal. Furthermore, the authors estimated that 30000 cymbals along a road of 100 $\mathrm{m}$ could generate an electrical power of $65 \mathrm{MWh}$ per year.

Not only the academia, but also the industry has shown some interest in this technology, as highlighted in Table 2.

\section{Comparison}

Each road energy harvesting system has positives, negatives and specific conditions to exploit the most of their potential in terms of energy output. At this scope, a comparison has been carried out in Table 3.

From the comparison, it is possible to draw the following observations:

- A common positive point is the ability of the systems to adjust the temperature of the asphalt, increasing the expected life of the pavement and reducing some related effect, as the Urban Heat Island;

- A common negative point is the interaction of the systems with the pavement performance. For example the presence of air voids in the interface between the solar collectors and the asphalt could accelerate the cracking;

- The electrical output of all the systems, except for the piezo-electric materials, depends strictly on the solar radiation.

- Optimization criteria depend on several parameters as the geometry of the system, the material's characteristics (i.e. the specific heat capacity or the thermal conductivity) and the efficiency of the technologies (i.e. the solar cells or thermoelectric generators). 
Table 2. List of companies which worked on piezoelectric pavement.

\begin{tabular}{|c|c|c|c|}
\hline Company & Description & $\begin{array}{l}\text { Electrical } \\
\text { output }\end{array}$ & Applications \\
\hline $\begin{array}{l}\text { Energy } \\
\text { Floors } \\
{[45]}\end{array}$ & $\begin{array}{l}\text { The floor is composed by a series of crystal and ceramic } \\
\text { piezoelectric blocks. The pavement can supply up to } 60 \text { percent of } \\
\text { the building's energy needs. }\end{array}$ & $\begin{array}{l}5-20 \\
W / \text { person }\end{array}$ & - $\quad$ London Club Surya (Rotterdam) \\
\hline $\begin{array}{l}\text { Genziko } \\
{[40]}\end{array}$ & $\begin{array}{l}\text { The Genziko system can generate electricity also after the passage } \\
\text { of the vehicles, exploiting the decaying vibration due the } \\
\text { instantaneous load of the wheel. }\end{array}$ & $\begin{array}{l}13-51 \\
\mathrm{MW} / \mathrm{km} \\
\text { (single } \\
\text { lane) }\end{array}$ & \\
\hline $\begin{array}{l}\text { Innowatech } \\
\text { [40] }\end{array}$ & $\begin{array}{l}\text { The piezoelectric materials are imbedded } 5 \mathrm{~cm} \text { below the surface } \\
\text { of the road and the system works better when the traffic is at least } \\
600 \text { vehicles/hour with an average speed of } 72 \mathrm{~km} / \mathrm{h}\end{array}$ & $\begin{array}{l}200 \\
\mathrm{kWh} / \mathrm{km}\end{array}$ & - $\quad$ Road in Israel \\
\hline $\begin{array}{l}\text { Sensitile } \\
\text { Systems } \\
{[46]}\end{array}$ & $\begin{array}{l}\text { The system consists of a piezoelectric layer enclosed between a } \\
\text { water proof cover and a flexible backing }\end{array}$ & $\begin{array}{l}25 \\
\mathrm{kWh} / \mathrm{km}\end{array}$ & $\begin{array}{ll}- & \text { Princess Grace, Monaco (pilot } \\
& \text { project) } \\
-\quad & 120 \text { meters of road in Medellin } \\
& \text { (energy and data harvester system) }\end{array}$ \\
\hline $\begin{array}{l}\text { Pavegen } \\
{[47]}\end{array}$ & $\begin{array}{l}\text { They developed a pavement block, with piezoelectric element } \\
\text { imbedded inside. Each people's step generates a vertical } \\
\text { displacement up to } 5 \mathrm{~mm} \text { and, consequently, an electric charge } \\
\text { occurs. }\end{array}$ & $46 \mathrm{~W} / \mathrm{m}^{2}$ & $\begin{array}{ll}- & 20 \mathrm{~m}^{2} \text { of pavement in Oxford Street } \\
& \text { (London, 2017); } \\
-\quad \text { Football pitches in Rio de Janeiro; } \\
-\quad \text { Heathrow Airport (London) }\end{array}$ \\
\hline
\end{tabular}

Table 3. Positives, negatives and optimization criteria for road energy harvesting systems.

\begin{tabular}{|c|c|c|c|}
\hline Technology & Positives & Negatives & Optimization criteria \\
\hline $\begin{array}{l}\text { Photovoltaic } \\
\text { road }\end{array}$ & $\begin{array}{l}\text { - Producing electricity thanks to the } \\
\text { solar cells } \\
\text { - Not invasive (some system are posed } \\
\text { on existing roads) }\end{array}$ & $\begin{array}{l}\text { - Dependent on the sunlight radiation } \\
\text { - Low friction of the glass surface } \\
\text { - Aging of top surface } \\
\text { - At high temperatures, the solar cells } \\
\text { lose efficiency }\end{array}$ & $\begin{array}{l}\text { - Maximize the exposure to sunlight } \\
\text { - Increase the transparency of the } \\
\text { top surface } \\
\text { - Increase the efficiency of the solar } \\
\text { cells }\end{array}$ \\
\hline $\begin{array}{l}\text { Asphalt solar } \\
\text { collectors }\end{array}$ & $\begin{array}{l}\text { - Providing hot water } \\
\text { - Snow-melting system } \\
\text { - Reducing Urban Heat Island (UHI) } \\
\text { - Increasing expected life of the } \\
\text { pavement (lowering the temperature } \\
\text { of the asphalt during the summer } \\
\text { and raising it during the winter) }\end{array}$ & $\begin{array}{l}\text { - Interference of the pipes with } \\
\text { pavement performance } \\
\text { - Presence of air voids between pipes } \\
\text { and mixture } \\
\text { - All pipes need to be interconnected } \\
\text { and if one is broken, fluid could } \\
\text { damage the asphalt }\end{array}$ & $\begin{array}{l}\text { - Increasing the Albedo* of the } \\
\text { surface } \\
\text { - Increasing the specific heat } \\
\text { capacity of materials } \\
\text { - Reducing the interference of the } \\
\text { pipes with the asphalt }\end{array}$ \\
\hline $\begin{array}{l}\text { Porous layer } \\
\text { as solar } \\
\text { thermal } \\
\text { system }\end{array}$ & $\begin{array}{l}\text { - Providing hot water } \\
\text { - Snow-melting system }\end{array}$ & $\begin{array}{l}\text { - Low strength of the porous layer } \\
\text { - Low permeability of the asphalt } \\
\text { mixture }\end{array}$ & $\begin{array}{l}\text { - Improving the permeability to } \\
\text { increase the harvested energy } \\
\text { - Using of semi-transparent layer to } \\
\text { maximize the heat transfer to the } \\
\text { porous layer }\end{array}$ \\
\hline $\begin{array}{l}\text { Air-Powered } \\
\text { Energy- } \\
\text { Harvesting } \\
\text { Pavement }\end{array}$ & $\begin{array}{l}\text { - Producing electric energy thanks to } \\
\text { the continuous airflow } \\
\text { - Absence of fluid into the conduits } \\
\text { - Reducing the temperature of the } \\
\text { pavement during summer and } \\
\text { increase the temperature during } \\
\text { winter }\end{array}$ & $\begin{array}{l}\text { - Low efficiency in terms of harvesting } \\
\text { energy (1\%) } \\
\text { - Aesthetic environmental impact of } \\
\text { the chimney }\end{array}$ & $\begin{array}{l}\text { - Optimizing the height and diameter } \\
\text { of chimney } \\
\text { - Increasing the total volume of the } \\
\text { air conducts } \\
\text { - Increasing the efficiency of the } \\
\text { turbine }\end{array}$ \\
\hline Heat Pipes & $\begin{array}{l}\text { - Snow-melting system } \\
\text { - Adjusting the asphalt temperature }\end{array}$ & $\begin{array}{l}\text { - Interference of the pipes with } \\
\text { pavement performance } \\
\text { - Presence of air voids between pipes } \\
\text { and mixture }\end{array}$ & $\begin{array}{l}\text { - Decrease the embedded spacing } \\
\text { (s), the embedded depth (d) and } \\
\text { the wind velocity }(\mathrm{v}) \text { to reduce the } \\
\text { time of the melting process } \\
\text { - Increase the embedded depth and } \\
\text { the heating power, decrease the } \\
\text { imbedded spacing and the wind } \\
\text { velocity to reduce the energy } \\
\text { absorbed by the environment }\end{array}$ \\
\hline $\begin{array}{l}\text { Thermoelectric } \\
\text { Generators }\end{array}$ & $\begin{array}{l}\text { - Producing electricity } \\
\text { - Adjusting the asphalt temperature }\end{array}$ & $\begin{array}{l}\text { - Low efficiency } \\
\text { - Poor research concerning the } \\
\text { applications of the system } \\
\text { - Interference of the TEGs with the } \\
\text { pavement performance }\end{array}$ & $\begin{array}{l}\text { - Increasing the temperature } \\
\text { gradient between the two sides of } \\
\text { the TEG }\end{array}$ \\
\hline $\begin{array}{l}\text { Piezo-electric } \\
\text { materials }\end{array}$ & - Producing electricity & $\begin{array}{l}\text { - Provide energy only for low-power } \\
\text { electronics (i.e. LED lights or } \\
\text { piezoelectric transducers) } \\
\text { - Interference of the cymbals with } \\
\text { pavement performance }\end{array}$ & $\begin{array}{l}\text { - Imbed piezo-electric materials in } \\
\text { road sections with high-traffic } \\
\text { volume }\end{array}$ \\
\hline
\end{tabular}

* It is the fraction of the incident sunlight reflected from a surface. Mathematically, it is given by the ratio between the reflected light and the incident light. For instance, the albedo of a black body is 0 , while the albedo of fresh deep snow is 0.9 
The road energy harvesting systems have been compared also in terms of cost, electrical output, Technology Readiness Level and Life Cycle Assessment (LCA) with respect to greenhouse gas (Table 4). The analyzed costs refer only to the construction costs, including the costs for materials. Other agency costs as preliminary engineering costs, contract administration, administrative, maintenance and rehabilitation costs [48] are not considered. Regarding the energy output, because of the different units used by the authors, all values are converted in $\mathrm{Wh} / \mathrm{m}^{2}$.

The efficiency is the ratio between the useful energy output and the energy input of the system and it is expressed in the range $0-1$.

The TRL (Technology Readiness Level) is a standard method to estimate the technology maturity of a system. It is based on a scale from 1 to 9 and each level is defined as follow:

TRL 1 - basic principles observed and reported; TRL 2 technology concept and/or application formulated; TRL 3 analytical and experimental critical function and/or characteristic proof of concept; TRL 4 - component validation in laboratory environment; TRL 5 - component validation in relevant environment; TRL 6 system/subsystem model or prototype demonstration in a relevant environment; TRL 7 system prototype demonstration in an operational environment; TRL 8 - actual system completed and qualified through tests and demonstration; TRL 9 - actual system proven in operational environment [49].

The Life-cycle Assessment (LCA) is a technique able to assess the potential environmental impact of a product throughout its entire life cycle. In the case of road pavements, LCA includes materials extraction and processing, construction, operation, preservation, rehabilitation, end of life phases, and factors such as traffic delay, lighting demand, and future maintenance [50]. For this review, the LCA is limited to the global warming potential (GWP), with respect to greenhouse gas (GHG).

Due to the lack of specific LCA studies about pavement energy harvesting technologies, the authors move from the GHG of a typical road pavement, at which they incorporate the GHG of the harvesting technologies (photovoltaic cell, solar thermal system, piezoelectric cymbal etc.). This approach provides qualitative data for a simplified comparison.

According to Ma et al. [51], the GHG of a road pavement composed of $18 \mathrm{~cm}$ of asphalt course, 34 centimeter of cement stabilized aggregate base and $20 \mathrm{~cm}$ cement stabilized gravel subbase is around $109 \mathrm{~kg}$ of $\mathrm{CO}_{2 \mathrm{e}} / \mathrm{m}^{2}(19 \mathrm{~kg}$ of $\mathrm{CO}_{2 \mathrm{e}} / \mathrm{m}^{2}$ for the asphalt course $+89.8 \mathrm{~kg}$ of $\mathrm{CO}_{2 \mathrm{e}} / \mathrm{m}^{2}$ for base and subbase). This value takes into account the emission from the raw material production and pavement construction.

The GHG of the pavement energy harvesting technology is calculated according to the following assumptions:

i) Photovoltaic pavement: the GHG of the asphalt course is replaced with the GHG of the photovoltaic cells (0.02-
$0.049 \mathrm{~kg}$ of $\mathrm{CO}_{2 \mathrm{e}} / \mathrm{kWh}[52,53] \approx 29.2-71.54 \mathrm{~kg}$ of $\mathrm{CO}_{2 \mathrm{e}}$ in 20 years and $0.2 \mathrm{kWh} / \mathrm{m}^{2}$ per day of electric output) and of a tempered surface glass of $1 \mathrm{~cm}(61.5 \mathrm{~kg}$ of $\left.\mathrm{CO}_{2 \mathrm{e}} / \mathrm{m}^{2}[54]\right)$.

ii) Asphalt solar collector: the total GHG is given adding the GHG of the asphalt solar collector measured by Siebert, E. Zacharakis [55] (48.9 $\mathrm{kg}$ of $\left.\mathrm{CO}_{2 \mathrm{e}} / \mathrm{m}^{2}\right)$.

iii) Porous layer as solar thermal system: the total GHG is given adding the GHG of a porous asphalt layer $(35 \mathrm{~kg}$ of $\mathrm{CO}_{2 \mathrm{e}}$ per ton [56]). Assuming a thickness of $4-8 \mathrm{~cm}[24$, 25] a density around $1.8 \mathrm{gr} / \mathrm{cm}^{3}$, the GHG is around 2.5 - $5 \mathrm{~kg}$ of $\mathrm{CO}_{2} / \mathrm{m}^{2}$. Replacing the asphalt with the porous concrete, the GHG increases up to $688.9-1271 \mathrm{~kg}$ of $\mathrm{CO}_{2 \mathrm{e}} / \mathrm{m}^{2}$ [57]. This latter is due to the carbon dioxide emission by the calcination of the limestone and by combustion of the fuels used to heat the kiln feed [58].

iv) Heat pipes: the heat pipes are placed under the asphalt course. According to the set-up of Zorn et al. [31], around 25 pipes cover a surface of $165 \mathrm{~m}^{2}$. The GHG of a single heat pipe is between 1055 and $6419 \mathrm{~kg}$ of $\mathrm{CO}_{2 \mathrm{e}}$ per unit [59]. The result is a GHG between 159.8 and $972.6 \mathrm{~kg}$ of $\mathrm{CO}_{2 \mathrm{e}} / \mathrm{m}^{2}$.

v) Thermoelectric generators: the total $\mathrm{GHG}$ is given adding the GHG of 19 TEGs modules per $\mathrm{m}^{2}$. The number of modules is given by the set-up proposed by Guo et Lu [37], while the GHG of a single module is 7.39 $\mathrm{kg}$ of $\mathrm{CO}_{2 \mathrm{e}}$ [60]. The result is a GHG of $66.51 \mathrm{~kg}$ of $\mathrm{CO}_{2 \mathrm{e}} / \mathrm{m}^{2}$.

vi) Piezoelectric pavement: the total GHG is given adding the piezoelectric cymbals under the asphalt course of the pavement. The GHG of the piezoelectric cymbals is between 31 and $44 \mathrm{CO}_{2 \mathrm{e}}$ per $\mathrm{kg}$ [61]. According to the set-up of Guo et Lu [36], 100 cymbals of $20 \mathrm{gr}$ each would generate a GHG between 62 and $88 \mathrm{~kg}$ of $\mathrm{CO}_{2 \mathrm{e}} / \mathrm{m}^{2}$.

Comparing data in Table 4, all costs are very high, but this is not surprising because the road energy harvesting technologies are mostly prototypes. Regarding the cost of TEG, it is unrealistic because the author considered only the price of the materials used to realize the prototype. In terms of efficiency, all the systems are around 0.1, except for the porous layer. This value could be increased for example improving the transparency of the top layer in photovoltaic roads, or improving the efficiency of the technologies to generate electricity (solar cells, TEGs and piezoelectric materials).

The highest electrical output is given by the photovoltaic roads, while the highest efficiency is given for the porous layer. The others systems provide lower values and they seem difficult to install in long road sections. For example, the piezoelectric pavements require a very high number of cymbals per $\mathrm{m}^{2}$ (up 1500, for cymbals with a diameter of $15 \mathrm{~mm}$ [37]) in order to generate an electrical power comparable with a photovoltaic road. 
Table 4. Cost, energy output, efficiency and TRL for different road energy harvesting systems. *in the case of porous concrete; **assuming: 100 cymbals per $\mathrm{m}^{2}, 100$ vehicle per hour.

\begin{tabular}{|c|c|c|c|c|c|}
\hline Technology & Cost $\left(€ / \mathrm{m}^{2}\right)$ & $\begin{array}{l}\text { Energy output } \\
\left(\mathrm{Wh} / \mathrm{m}^{2}\right)\end{array}$ & $\begin{array}{l}\text { Efficiency } \\
(0-1)\end{array}$ & TRL & $\begin{array}{l}\text { GHG } \\
\left(\mathrm{kg} \text { of } \mathrm{CO}_{2 \mathrm{e}} / \mathrm{m}^{2}\right)\end{array}$ \\
\hline Photovoltaic road & $400-1700[62,63]$ & $\approx 200[13]$ & $0.11[3]$ & $7[3]$ & $180.6-222.9$ \\
\hline Asphalt solar collectors & 290 [37] & NA & NA & 9 & 157.8 \\
\hline $\begin{array}{l}\text { Porous layer as solar thermal } \\
\text { system }\end{array}$ & NA & NA & $\begin{array}{l}0.31-0.41[26,27] \\
\text { (+0.07 using a semi- } \\
\text { transparent layer) }\end{array}$ & 4 & $\begin{array}{l}111.4-113.9 \\
688.9-1271^{*}\end{array}$ \\
\hline $\begin{array}{l}\text { Air-Powered Energy-Harvesting } \\
\text { Pavement }\end{array}$ & NA & NA & $0.15[29]$ & 3 & NA \\
\hline Heat pipes & $1000-1600[64]$ & NA & NA & $5[2]$ & $268.7-1081$ \\
\hline Thermoelectric Generator & $\begin{array}{l}80 \text { (refers to the test } \\
\text { cost) [66] }\end{array}$ & $\approx 3[67]$ & $0.01-0.08[65]$ & $5[66]$ & 175.4 \\
\hline Piezo-electric Material & $1130[37]$ & $\approx 7.5-12.5[37]^{* *}$ & $0.10-0.15[40]$ & $4[2]$ & $170.9-196.9$ \\
\hline
\end{tabular}

The porous layer as solar thermal system has the lowest carbon footprint, thanks to the low value of porous asphalt GHG. However, this value could increase adding a heat pump for exploiting the harvested heat energy.

\section{Conclusions}

In order to harvest energy from pavement, the solar radiation can be converted into electricity thanks to solar cells placed under a semi-transparent layer (photovoltaic road), or it can be harvested by means of a heat-transfer fluid (thermal solar systems). The traditional way consists of a pipe network imbedded into the asphalt, in which the water flows, extracting heat energy from the pavement (asphalt solar collectors). Another approach is to replace the pipe network with a porous layer, in which the water flows via gravity.

The photovoltaic road and the porous layer as solar thermal system seem to be the most promising for the energy harvesting. Anyhow, these technologies require further studies because they still present some critical issues. Based on the literature review, the following negatives can be listed for the photovoltaic road:

1. The power loss of the solar cells because of the semitransparent layer could be very high;

2. The efficiency of the solar cells is reduced around noon time, because the pavement reach the highest temperatures;

3. The use of epoxy as binder in the top layer is not recommended because it is strongly affected by aging. This phenomenon has an impact on the optical and mechanical performance of the semi-transparent layer.

Regarding the porous layer as solar thermal system, the negatives are:

1. The poor harvested energy because of the low porosity of middle layer, which is maximum $20-23 \%$ for a porous asphalt mixture;

2. The poor strength of the porous layer;

Moving from the observations, for the photovoltaic roads the challenge is the mix-design of a novel semi-transparent layer having low power loss and characterized by high aging resistance, while for the porous solar thermal system is to maximize the porosity (i.e. using porous concrete), but keeping an adequate strength.
The semi-transparent layer appears to be very important for both the photovoltaic efficiency and the thermal transfer in deeper layers. Hence, from a research point of view, the main challenge concerns the design and the optimization of the semi-transparent layer able to support the traffic load, guarantee the vehicles friction, allow the passage of the sunlight, protect the solar cells and maximize the heattransfer to the porous layer.

\section{Funding}

The research presented in this paper is part of SMARTI ETN. SMARTI ETN project and received funding from the European Union's Horizon 2020 Programme under the Marie Skłodowska-Curie actions for research, technological development and demonstration, under grant n.721493.

\section{CRediT authorship statement}

Domenico Vizzari: Conceptualization, Methodology, Software, Validation, Formal Analysis, Investigation, Resources, Data Curation, Writing - original draft, Writing review and editing, Visualization.

Eric Gennesseaux: Conceptualization, Methodology, Supervision.

Stéphane Lavaud: Conceptualization, Methodology, Supervision.

Stéphane Bouron: Conceptualization, Investigation, Resources.

Emmanuel Chailleux: Conceptualization, Methodology, Validation, Investigation, Supervision, Project administration, Funding acquisition.

\section{References}

[1] M. M. Tentzeris, A. Georgiadis, L. Roselli, Energy Harvesting and Scavenging. Proceedings of the IEEE (2014) Vol. 102, No. 11. https://doi.org/10.1109/JPROC.2014.2361599

[2] R. Fedele, M. Merenda, F. G. Praticó, R. Carotenuto, F. G. Della Corte, Energy harvesting for loT road monitoring systems. Instrum Mes Metrol (2018) 17: 605

https://doi.org/10.3166/i2m.17.605-623

[3] F. Duarte, Ferreira A., Energy harvesting on road pavements: state of the art. Proceedings of the Institution of Civil Engineers (2015). https://doi.org/10.1680/iener.15.00005

[4] G. Castillo-Garcia, E. Blanco-Fernandez, P. Pascual-Muñoz, D. CastroFresno, Energy harvesting from vehicular traffic over speed bumps: $A$ review. Energy (2018) 171(2): 58-69. https://doi.org/10.1680/iener.17.00008 
[5] D. Vizzari, P. Puntorieri, F. Praticó, V. Fiamma, G. Barbaro: Energy harvesting from solar and permeable pavements: A feasibility study. Annales De Chimie-science Des Materiaux (2018) 42: 502-520. https://doi.org/10.3166/acsm.42.502-520

[6] A. Dawson, R. Mallick, A. H. Garcia, P. K. Dehdezi, Energy Harvesting from Pavements (2014). Springer Berlin Heidelberg. Chapter 18. https://doi.org/10.1007/978-3-662-44719-2_18

[7] A. Northmore, S. Tighe, Innovative Pavement Design: Are Solar Roads Feasible? Conference of the Transportation Association of Canada (2012).

[8] National Electrical Manufacturers Association, Nema Standards publications Li 1-1998. Industrial Laminating Thermosetting Products. 1. (2011)

[9] A. S. Dezfooli, F. M. Nejad, H. Zakeri, S. Kazemifard, Solar pavement: A new emerging technology. Solar Energy (2017) 149:272-284. https://doi.org/10.1016/j.solener.2017.04.016

[10] T. Ma, H. Yang, W. Gu, Z. Li, S. Yan, Development of walkable photovoltaic floor tiles used for pavement. Energy Conversion and Management (2019) 183: 764-771. https://doi.org/10.1016/j.enconman.2019.01.035

[11] J. Brusaw, http://www.solarroadways.com/ Accessed July 2021.

[12] Wattway - Press Kit: Paving the way to tomorrow's energy. (2016) Colas.

[13] R.E. Van Gorkum, N. Brouwer, A. Kamper, http://www.oomspmb.com/products/special-products-/solaroad/ Accessed July 2021.

[14] A. R. Patila, V. Y. Khairnara, A. V. Kokatea, R. S. Narkhedea, A Novel Route for Construction of Smart Highways by Using Photovoltaic Solar Panels. IJRAR (2018), Vol 5, Issue 3.

[15] S. Bouron, E. Chailleux, A. Themeli, J. Dumoulin, C. Ropert, Revêtement translucide pour la production d'énergie électrique. Revue générale des routes et de l'aménagement. (2017) RGRA, 949: 76-79.

[16] D. Vizzari, E. Chailleux, E. Gennesseaux, S. Lavaud, N. Vignard, Viscoelastic characterisation of transparent binders for application on solar roads. Road Materials and Pavement Design (2019) 20: 112-126. https://doi.org/10.1080/14680629.2019.1588774

[17] D. Vizzari, E. Chailleux, S. Lavaud, E. Gennesseaux, S. Bouron, raction Factorial Design of a Novel Semi-Transparent Layer for Applications on Solar Roads. Infrastructures (2020) 5 (1): 5. https://doi.org/10.3390/infrastructures5010005

[18] A. Themeli, Post-doc report. (2017) IFSTTAR.

[19] V. Bobes-Jesus, P. Pascual-Munoz, D. Castro-Fresno, J. RodriguezHernandez, Asphalt solar collectors: A literature review. Applied Energy (2013) 102: 962-970. https://doi.org/10.1016/i.apenergy.2012.08.050

[20] W. J. Eugster, Road and Bridge Heating Using Geothermal Energy. Overview and Examples. Proceedings European Geothermal Congress (2007).

[21] M. Hewitt, http://www.icax.co.uk/ Accessed July 2021

[22] C. Sullivan, A. Bont, R. Jansen, H. Verweijmeren, Innovation in the production and commercial use of energy extracted from asphalt pavements. (2006).

[23] A. Scaht, M. Munk, C. Busen, M. Osser, B. Steinauer, Application of a porous interlayer for road temperature control. In XIV International Winter Road Congress, Institute for road and traffic engineering, RWTH. Aachen University, Deutschland, PIARC, Andoraa la Vella (2012).

[24] S. Asfour, F. Bernardin, E. Toussaint, J. M. Piau, Hydrothermal modeling of porous pavement for its surface de-freezing. Applied Thermal Engineering (2016) 107: 493-500. https://doi.org/10.1016/j.applthermaleng.2016.06.138

[25] P. Pascual-Munoz, D. Castro-Fresno, P. Serrano-Bravo, A. AlonsoEstébanez, Thermal and hydraulic analysis of multilayered asphalt pavements as active solar collectors. Applied Energy (2013) 111: 324332. https://doi.org/10.1016/j.apenergy.2013.05.013

[26] N. Le Touz, T. Toullier, J. Dumoulin, Infrared thermography applied to the study of heated and 18 solar pavement: from numerical modeling to small scale laboratory experiments. SPIE - 19 Thermosense: Thermal Infrared Applications XXXIX (2017), Anaheim, United States. https://doi.org/10.1117/12.2262778

[27] N. Le Touz, J. Dumoulin, J. Piau, Multi-physics fem model of solar hybrid roads for energy harvesting performance evaluation in presence of semi-transparent or opaque pavement surface layer. IHTC 2018 - 16th International Heat Transfer Conference (2018), Beijing, China. https://doi.org/10.1615/IHTC16.cms.023896

[28] A. Garcia, Partl M. N., How to transform an asphalt concrete pavement into a solar turbine. Applied Energy (2014) 119: 431-437. https://doi.org/10.1016/j.apenergy.2014.01.006

[29] A. Chiarelli, A. R. Dawson, A. Garcia, Parametric analysis of energy harvesting pavements operated by air-convection. Applied Energy (2015) 154: 951-958. https://doi.org/10.1016/j.apenergy.2015.05.093

[30] M. Uddi, https://www.youtube.com/watch?v=2vk5B6Gga10 Accessed July 2021.

[31] R. Zorn, H. Steger, T. Kolbel, De-lcing and Snow Melting System with Innovative Heat Pipe Technology. Proceedings World Geothermal Congress (2015).

[32] A. D. Chiasson, Geothermal Heat Pump and Heat Engine Systems: Theory And Practice. ASME press and Wiley \& Sons (2016). https://doi.org/10.1002/9781118961957

[33] Liu K., Huang S., Xie H. and Wang F.: Multi-objective optimization of the design and operation for snow-melting pavement with electric heating pipes. Applied Thermal Engineering 122: 359-367. https://doi.org/10.1016/i.applthermaleng.2017.05.033

[34] G. J. Snyder and E. S. Toberer, Complex thermoelectric materials. Nature materials (2008) 7: 105-114. https://doi.org/10.1038/nmat2090

[35] C. J. M. Lasance, The Seebeck Coefficient. Articles, Design, Test \& Measurement (2006).

[36] M. Hasebe, Y. Kamikawa, S. Meiarashi, Thermoelectric generators using solar thermal energy in heated road pavement. Proceedings ICT '06 - 25th international conference on thermoelectrics (ICT), Vienna, Austria (2006). https://doi.org/10.1109/ICT.2006.331237

[37] L. Guo, Q. Lu, Potentials of piezoelectrics and thermoelectric technologies for harvesting energy from pavements. Renewable and Sustainable Energy Reviews (2017) 72: 761 - 773. https://doi.org/10.1016/j.rser.2017.01.090

[38] G. Wu, B. Yu, System Design to Harvest Thermal Energy Across Pavement Structure. IEEE Energytech, Cleveland (2012).

[39] D. Vatansever, E. Siores, T. Shah, Alternative Resources for Renewable Energy: Piezoelectric and Photovoltaic Smart Structures. Global Warming - Impacts and Future Perspective. (2017) Bharat Raj Singh (Eds.).

[40] D. Hill, A. Agarwal, N. Tong, Assessment of piezoelectric materials for roadway energy harvesting. Cost of Energy and Demonstration Roadmap. California Energy Commission (2014).

[41] H. Zhao, J. Yu, J. Ling, Finite element analysis of Cymbal piezoelectric transducers for harvesting energy from asphalt pavement. Journal of the Ceramic Society of Japan (2010) 118: 909-915. https://doi.org/10.2109/jcersj2.118.909

[42] C. Sun, G. Shang, Y. Zhang, Designing piezoelectric harvesting unit from road vibration. Adv Mater Res (2013) 712 - 715: 1368-1371. https://doi.org/10.4028/www.scientific.net/AMR.712-715.1368

[43] H. Xiong, L. Wang, Piezoelectric energy harvester for public roadway: On-site installation and evaluation. Applied Energy (2016) 174: 101107. https://doi.org/10.1016/j.apenergy.2016.04.031

[44] A. Moure, M. A. I. Rodriguez, S. H. Rueda, A. Gonzalo, F. R. Marcos, D. U. Cuadros, A. P. Lepe, J. F. Fernandez, Feasible integration in asphalt of piezoelectric cymbals for vibration energy harvesting. Energy Conversion and Management (2016) 112: 246-253. https://doi.org/10.1016/i.enconman.2016.01.030

[45] A. M. Arjun, S. Ajay, T. Sandhya, V. Arvind, A Novel Approach to Recycle Energy Using Piezoelectric Crystals. International Journal of Environmental Science and Development (2011) 2 (6): 488-492. https://doi.org/10.7763/IJESD.2011.V2.175

[46] A. Lath, https://www.sensitile.com/projects/powerleap Accessed July 2021.

[47] L. Kemball-Cook, https://pavegen.com/ Accessed July 2021.

[48] J. Walls III, M. R. Smith, Life Cycle Cost Analysis in Pavement Design (1998) Report no. FHWA-SA-98-079.

[49] J. Mankins, Technology Readiness Level - A White Paper. Advanced Concepts Office Office of Space Access and Technology, NASA (1995).

[50] J. T. Harvey, J. Mejer, H. Ozer, I. L. Al-Qadi, A. Saboori, A. Kendall: Pavement life-Cycle Assessment Framework (2016). Report No. FHWA-HIF-16-014.

[51] F. Ma, A. Sha, R. Lin, Y. Huang and C. Wang: Greenhouse Gas Emissions from Asphalt Pavement Construction: A Case Study in China. Int. J. Environ. Res. Public Health (2016) 13: 351; https://doi.org/10.3390/ijerph13030351

[52] A. Louwen, W. Van Sark, A. Faaij, R Schropp: Re-assessment of net energy production and greenhouse gas emissions avoidance after 40 years of photovoltaics development. Nature Communications (2016). https://doi.org/10.1038/ncomms13728 
[53] V. M. Fthenakis abd H. C. Kim: Greenhouse-gas emissions from solar electric- and nuclear power: A life-cycle study. Energy Policy (2007) 35, 2549-2557. https://doi.org/10.1016/j.enpol.2006.06.022

[54] H. W. Kua, Y. Lu: Environmental impacts of substituting tempered glass with polycarbonate in construction - An attributional and consequential life cycle perspective. Journal of Cleaner Production (2016), 137, 910 - 921. https://doi.org/10.1016/j.jclepro.2016.07.171

[55] N. Siebert, E. Zacharakis: Asphalt Solar Collector and Borehole Storage Design study for a small residential building area (2010). Report No. E2010:11.

[56] D. E. G. Bizarro, Z. Steinmann, I. Nieuwenhuijse, E. Kejzer, M. Hauck: Potential Carbon Footprint Reduction for Reclaimed Asphalt Pavement Innovations: LCA Methodology, Best Available Technology, and Near-Future Reduction Potential. Sustainability (2021), 13, 1382. https://doi.org/10.3390/su13031382

[57] X. Chen, H. Wang, H. Najm, G. Venkiteela, J. Hencken: Evaluating engineering properties and environmental impact of pervious concrete with fly ash and slag. Journal of Cleaner Production (2019) 237: 117714. https://doi.org/10.1016/i.jclepro.2019.117714

[58] L. Barcelo, J. Kline, G. Walenta: Cement and carbon emissions. Materials Structures (2014) 47: 1055-1065. https://doi.org/10.1617/s11527-013-0114-5

[59] W. Zhao, L. Zhen, S. Hongmin: Life Cycle Assessment of District Heating Distribution Networks in China - Pipe Production. Applied Mechanics and Materials (2013) 256-259: 2652-2655. https://doi.org/10.4028/www.scientific.net/AMM.256-259.2652

[60] Y. Kishita, M. Uwasu, H. Takeda, K. Hara: Assessing the greenhouse gas emissions and cost of thermoelectric generators for passenger automobiles: a life cycle perspective. Proceedings of the ASME 2014 International Design Engineering Technical Conferences \& Computers and Information in Engineering Conference (2014) IDETC/CIE. https://doi.org/10.1115/DETC2014-34483

[61] T. Ibn-Mohammed, I.M. Reaney, S.C.L. Koh, A. Acquaye, D.C. Sinclair, C.A. Randall, F.H. Abubakar, L. Smith, G. Schileo, L. Ozawa-Meida: Life cycle assessment and environmental profile evaluation of lead-free piezoelectrics in comparison with lead zirconate titanate. Journal of the European Ceramic Society (2018) 38: 4922-4938. https://doi.org/10.1016/i.jeurceramsoc.2018.06.044

[62] F. Todd, https://www.nsenergybusiness.com/features/china-solarhighway-energy/Accessed July 2021.

[63] K. Willsher, https://www.theguardian.com/environment/2016/dec/22/solarpanel-road-tourouvre-au-perche-normandy Accessed July 2021.

[64] Lund J. W.: Pavement snow melting. Geo-Heat Center, Oregon Institute of Technology (2005) Klamath Falls, OR.

[65] W. Chen, P. Wu, X. Wang, Y. Lin, Power output and efficiency of a thermoelectric generator under temperature control. Energy Conversion and Management (2016) 127: 404-415. https://doi.org/10.1016/j.enconman.2016.09.039

[66] W. Jiang, D. Yuan, S. Xu, H. Hu, J. Xiao, A. Sha, Y. Huang, Energy harvesting from asphalt pavement using thermoelectric technology. Applied Energy (2017) 205: 941-950. https://doi.org/10.1016/j.apenergy.2017.08.091

[67] S. A. Tahami, M. Gholikhani, S. Dessouky, Thermoelectric Energy Harvesting System for Roadway Sustainability. Transportation Research Board (2020). https://doi.org/10.1177/0361198120905575 